\title{
The Influence of E-Counselling Application on the Students' Counselling Interest
}

\author{
Paramita Nuraini ${ }^{1 *}$, Nofi Nur Yuhenita ${ }^{1}$, Endah Ratna Arumi ${ }^{2}$ \\ ${ }^{1}$ Faculty of Teacher Training and Education, Universitas Muhammadiyah Magelang, Magelang, Indonesia \\ ${ }^{2}$ Faculty of Engineering, Universitas Muhammadiyah Magelang, Magelang, Indonesia \\ *Corresponding author. Email: paramitanuraini@ummgl.ac.id
}

\begin{abstract}
Counselling services in schools represent teachers' responsibility on students in solving their problems. It is purposed to develop their value optimally. The students were not eager to consult their problems through guidance and counselling services. This study aims to determine the effects of e-counselling application on students' counselling interests. It employed Pre-test \& post-test control design. 80 students participated in this study consisting of 40 males and 40 females. It used purposive sampling technique. Questionnaire was administered to collect the data. The score of the experimental group showed greater than the control one after the treatment. The statistical calculation revealed that the value of sig. (2-tailed) was $0.009>0.05$. Parametric analysis (ANOVA) was conducted to analyse them. The results showed that the application affected students' counselling interests.
\end{abstract}

Keywords: e-counselling, application, counselling interest

\section{INTRODUCTION}

Guidance and counselling contain educational values and functions to glorify humanity so that humans can live effectively. Practically, the counselling process will deliver an individual to a pleasant, safe, and effective state in his daily life [1]. As a result, it is crucial for the school to play its role as a place for students to study and adapt to a new environment. Therefore, school is not only a place to transfer knowledge but also a place to develop students' self-potential in academics, spirituals, and personalities. SMP Muhammdiyah Pujotomo Magelang,Indonesia, is a school located in Magelang regency. It experiences a problem with the low students' counselling interest. Many students think that counsellors deal with problematic and naughty students. They also think that the counsellors' duty is to scold and punish the students who break the school's rules so that counsellors are positioned as the school's police. This assumption leads to the students' reluctance and shame to come to guidance and counselling room to have counselling. Another factor makes the low interest of counselling is the less representative room of guidance and counselling as the room is usually next to the teachers' room. It causes the students to feel uncomfortable since they worried about the leak out talks by the other teachers. The other factor is the need to document the counselling. The documentation takes a long time and therefore sometimes it could not be well documented. Hence, the homeroom teachers and parents cannot monitor the students' counselling. The aforementioned factors result in ineffective counselling in SMP Muhammadiyah Pujotomo and lessen students' counselling interest.
Interest is someone's willingness to perform real actions. Theory of Reasoned Action (TRA), developed by Ajzen dan Fishbein explained that actions are carried out due to individual's interest or willingness [2]. Mentions that an activity will be well conducted if there is an interest from the doer [3]. In other words, the high interest leads to a wellconducted activity. The interest could be generated by linking objects (guidance and counselling services) with experiences and knowledge gained through information. The statements reflect this study in which students' counselling interest will affect the counselling process itself, and hence, the interest is a must in counselling process.

Social network or social networking is an application that allows users to be able to communicate by exchanging information, comments, messages, pictures, and audiovideo. In social networks, users are facilitated to interact, communicate and collaborate [4]. This statement contributes to this research that, mechanisms in socializing and exchanging information through this network have been proven to improve interpersonal relationships and can provide facilitation to improve nonverbal communication through media such as images, audio and video.

In the technology era, the counsellors' competences in applying technology in the therapy process need to continue to be developed. The competences include the basic knowledge to achieve by the counsellors such as the data processing program, audio-visual tools, e-mail, internet, list server, and CD-ROM data base. Video streaming and wireless connection are the current technology affecting the counsellors' performance in the future [5]. This situation challenges the counsellors. The emergence of internet helps the counsellors in finding references and conducting not only face-to-face counselling process but also distance counselling with the help of the internet which is called as e-counselling [6]. E-counselling also helps the counsellors in archiving the data and keeping all counselling recordings. Based on the above description, the scientific study investigating the influence of e-counselling application on 
the students' counselling interest in SMP Muhammadiyah Pujotomo Magelang needs to be conducted.

\section{METHOD}

The study employed quasi-experiment research. It was conducted to 80 students in SMP Muhammadiyah Pujotomo. This study applied the Pre-test \& post-test control group design with one treatment. The samples, 80 students, were divided into two groups: 40 students belong to experimental group (the group achieving e-counselling application) and 40 students belong to the control group (the group that does not achieve the treatment). Purposive sampling was used as the sampling technique. Questionnaire on students' interest was used as the instrument to collect the data. The data analysis technique applied was parametric analysis in form of Anova (Analysis of Variance) with the help of SPSS program for windows version 22.00.

The first step is to give the initial test (pre-test) to the group of Experiments and control group to measure the initial conditions before the treatment $(\mathrm{X})$ is the use of ecounselling application. After pre-test the control group is given the treatment of use e-counselling application, while the control group is not done using the e-counselling application. Subsequently given a post-test with a nod of interest counselling.

Table 1 Research draft

\begin{tabular}{|llll|}
\hline Experimental Group & $\mathrm{O} 1$ & $\mathrm{X}$ & $\mathrm{O} 2$ \\
\hline Control Group & $\mathrm{O} 3$ & - & $\mathrm{O} 4$ \\
\hline Description: O1 and O2: Pre test; $X:$ Treat $;-$-: Not given treatment; O3
\end{tabular}
and 04 : Post test

\section{RESULTS AND DISCUSSION}

The result reveals that e-counselling application affects the students' counselling interest. It is proven from the different scores of the interest scale between experimental and control group in which the increased score of experimental groups is greater than the control group. The parametric analysis using ANOVA on experimental and control group shows probability value sig ( 2 -tailed) $0,000<0,05$. Student interests increase by using the E-counselling application. The e-counselling app helps students to be more open in delivering the problems experienced. The results of statistical calculations using ANOVA is presented in Table 1.

Table 2 Score

\begin{tabular}{|c|c|c|c|c|c|}
\hline & Sum of Squares & df & Mean Square & $\mathbf{F}$ & Sig. \\
\hline Between Groups & 32370.550 & 3 & 10790.183 & 311.454 & .000 \\
\hline Within Groups & 5404.550 & 156 & 34.645 & & \\
\hline Total & 37775.100 & 159 & & & \\
\hline
\end{tabular}

This result is in line with Ifdil [7] stating that counsellors should possess technological skills and minimum administration skills in e-counselling, at least the knowledge of basic e-counselling services. The statement supports the previous research mentioning that technological mastery and application in the guidance and counselling process is a must in this era. E-counselling helps the counsellors in solving the counselees' problems. Counselling is designed to help the clients in understanding and interpreting their point of view towards life and to help them achieve self-determination through options and information delivered and through problem solving, emotions, and interpersonal characteristics [8]. This statement supports this current study in terms of the importance of counselling for students to help them develop their potential and thus leading to optimal self-actualization. Through the e-counselling application, students feel more comfortable in the counselling process.

\section{CONCLUSION}

Based on the result of the study, it can be concluded that the e-counselling application influences the increase of the students' counselling interest in SMP Muhammadiyah Pujotomo Magelang. Increasing student interest in counselling should be supported with the ability and skills of counsellors in the use of media or counselling applications. E-Counselling application is used to facilitate students in conducting counselling activities because with e-counselling application makes it easy for students to express their problems with counsellors so that counsellors have A comprehensive understanding of the Consley problem so that it is able to intervene correctly the contemplated problem.

\section{REFERENCES}

[1] Prayitno, Wawasan Profesi Konseling. Padang: Universitas Negeri Padang, 2009.

[2] Jogiyanto, Sistem Informasi Keperilakuan. Yogyakarta: Andi Offset, 2007.

[3] J. Greenhow, C. G., Robelia, B., \& Hughes, “). Learning, teaching, and scholarship in a digital age Web 2.0 and classroom research: What path should we take now?," Educ. Res., vol. 4, no. 38, pp. 246-259, 2019.

[4] A. Salahudin, Bimbingan Dan Konseling. Bandung: Pustaka Setia, 2010. 
[7] I. Ifdil, "Konseling Online Sebagai Salah Satu

[5] S. . Glading, Konseling Profesi Yang Menyeluruh. Alih Bahasa Winarno dan Lilian, 2012.

[6] M. H. Gibson, R.L. \& Mitchell, Introduction to Counseling and Guidance. New York: Macmillan Publisher, 2008.
Bentuk Pelayanan E-konseling," J. Konseling dan Pendidik., vol. 1, no. 1, pp. 15-23, 2013.

[8] J. McLeod, Pengantar Konseling; Teori dan Studi Kasus (Edisi Ketiga) (Alih Bahasa: A.K Anwar). Jakarta, 2008. 